Artikel Penelitian

\title{
Gambaran Pelayanan Swamedikasi Oleh Apoteker Di Kota Palu
}

\author{
An Overview Of Self-medication Services By Pharmacists In The \\ Palu City
}

\author{
Nurintan Kurnia Manikam*, Amelia Rumi, Firdawati Amir Parumpu \\ Jurusan Farmasi, ,Fakultas Matematika dan Ilmu \\ Pengetahuan Alam, Universitas Tadulako, Jl Soekarno \\ Hatta No. KM.9, Tondo, Mantikulore, Kota Palu, \\ Sulawesi Tengah 94148, Indonesia \\ *E-mail: nurintankurniamanikam@gmail.com
}

\begin{abstract}
Abstrak
Pelayanan swamedikasi yang baik adalah swamedikasi yang dilakukan oleh tenaga ahli obat yaitu apoteker untuk mengoptimalkan penggunaan obat dan meningkatkan kesehatan. Pada saat yang bersamaan, apoteker juga diharapkan dapat memberikan konsultasi kepada pasien dan memantau setiap masalah yang mungkin terjadi selama penggunaan obat, yang disebut dengan masalah terkait obat (Medication error). Tujuan penelitian ini adalah untuk mengetahui gambaran pelayanan swamedikasi oleh apoteker di kota palu berdasarkan kategori penggalian informasi, pemilihan obat dan informasi obat. Metode penelitian yang digunakan adalah deskriptif kualitatif bersifat cross sectional dan metode pengambilan sampel adalah Purposive sampling. Kriteria responden yaitu apoteker yang memiliki SIPA aktif dan berpraktek di apotek serta bersedia menandatangani lembar Informed consent. Berdasarkan kriteria tersebut, diperoleh 86 sampel apoteker dalam apotek yang berada di Kota Palu. Instrumen yang digunakan yaitu menggunakan kuesioner dalam bentuk Google Form yang telah dilakukan uji validitas dan uji reliabilitas serta data yang diperolehdievaluasi secara deskriptif. Hasil penelitian menunjukkan bahwa apoteker dalam apotek di kota palu sudah melaksanakan pelayanan swamedikasi untuk penggalian informasi sebesar $83,60 \%$, pemilihan obat sebesar $95,35 \%$ dan pemberian informasi obat sebesar $89,66 \%$. Kesimpulan dari penelitian ini yaitu apoteker dalam apotek sudah melaksanakan pelayanan swamedikasi dengan baik sesuai variabel.
\end{abstract}

Kata kunci: pelayanan swamedikasi, apoteker, apotek

Abstract

A good self-medication service is self-medication carried out by drug experts, namely pharmacists to optimize drug use and improve health. At the same time, pharmacists are also expected to be able to provide consultations to patients and monitor any problems that may occur during drug use, which are called drug-related problems (Medication error). The purpose of this study was to determine the description of self-medication 
services by pharmacists in the city of Palu based on the categories of extracting information, drug selection and drug information. The research method used is descriptive qualitative cross sectional and the sampling method is purposive sampling. The respondent's criteria are pharmacists who had activated SIPA and practised in pharmacies along are willing to signs an informed consent form. Based on these criteria, had obtained 86 samples of pharmacists in pharmacies in Palu City. The instrument used is using a questionnaire in the form of Google Form which had been tested for validity and reliability testing and the data obtained is evaluated descriptively. The results showed that pharmacists in pharmacies in Palu City had carried out self-medication services for extracting information by $83.60 \%$, drug selection by $95.35 \%$ and providing drug information by $89.66 \%$. The conclusion of this studied is that pharmacists in pharmacies had carried out self-medication serviced properly according to variables.

Keywords: self-medication service, pharmacist, pharmacy

\section{PENDAHULUAN}

Apoteker merupakan profesi yang ahli dalam tindakan dan aplikasi obat, termasuk sifat kimianya, cara dirumuskan sebagai obat dan cara penggunaannya untuk pengendalian penyakit. Tujuan utama apoteker adalah menggunakan keahlian ini untuk memaksimalkan keselamatan pasien. Apoteker berhubungan langsung dengan pasien dan memiliki peran penting dalam hal membantu pasien menggunakan obat sebaik mungkin serta menasihati pasien tentang penanganan mandiri yang tepat untuk gejala yang dialami (Rees, 2013). Salah satu bentuk layanan apoteker yaitu pelayanan swamedikasi.

Pelayanan swamedikasi adalah penggunaan dan pemilihan obat-obatan yang digunakan orang untuk mengobati penyakit maupun gejala tanpa resep dokter (Widyaningsih, 2018). Penerapan pelayanan swamedikasi harus sesuai standar pengobatan yang wajar, yaitu tepat pasien, tepat obat, tepat dosis, kewaspadaan terhadap efek samping obat dan interaksi obat. Sejalan dengan perkembangan zaman, semakin banyak orang yang menerapkan pengobatan sendiri dari semua lapisan masyarakat tidak hanya para sarjana. Faktor yang meningkatkan praktek pengobatan sendiri antara lain kesadaran masyarakat akan hidup sehat dan berbagai penyakit serta media pemasaran (Candradewi \& Kristina, 2017).

Ada banyak kesalahan pengobatan dalam pelaksanaan swamedikasi. Kesalahan pengobatan atau disebut juga Medication error disebabkan pengetahuan masyarakat yang terbatas tentang obat, pengaplikasian dan informasi obat (Zeenot, 2013). Menurut penelitian Lubis (2014) kesalahan swamedikasi didapatkan sebanyak $40,1 \%$ kasus. Masalah yang sering terjadi dalam medication error adalah kesalahan dalam menentukan obat, dosis yang berlebihan, tidak rasional seperti penggunaan antibiotik (Osemene \& Lamikanra, 2012). Oleh karena itu, masyarakat mempunyai hak atas informasi yang akurat, benar, lengkap, tidak memihak dan tidak menyesatkan. Jadi apoteker memegang peranan penting terhadap pelaksanaan pengobatan sendiri. 
Berdasarkan penjelasan di atas, maka didapatkan data apoteker yang berpraktik di apotek-apotek kota Palu rata-rata $100 \%$ telah melakukan kegiatan pelayanan swamedikasi terhadap masyarakat, maka penting untuk mengetahui sejauh mana apoteker dalam apotek menerapkan pelayanan swamedikasi terutama di wilayah kota palu sehingga membuat peneliti tertarik untuk melakukan penelitian ini.

\section{BAHAN DAN METODE}

\section{Desain Penelitian}

Desain penelitian ini adalah deskriptif kualitatif bersifat cross sectional dan teknik pengambilan data secara purposive sampling selama 2 bulan (JuniAgustus 2021) pada apoteker yang memenuhi kriteria inklusi dan ekslusi. Kriteria inklusi penelitian ini adalah apoteker yang memiliki SIPA aktif dan berpraktik di apotek serta bersedia mengisi Informed consent. Kriteria ekslusinya yaitu apoteker yang tidak selesai atau tidak lengkap mengisi kuesioner. Populasi apoteker yang didapatkan sebanyak 110 apoteker dalam apotek yang selanjutnya sampel dihitung menggunakan rumus slovin sehingga didapatkan sampel sebanyak 86 apoteker dalam apotek.

\section{Prosedur Pengambilan Data}

Proses pengambilan data dengan menyebarkan google form secara daring dan luring dalam bentuk hardcopy kepada apoteker di Kota Palu. Pengambilan data melalui google form dilakukan untuk apoteker yang memenuhi kriteria inklusi dan pada saat penelitian masih dalam keadaan pandemi. Pengambilan data secara luring dilakukan untuk apoteker yang tidak memiliki waktu atau terkendala jaringan untuk mengisi google form sehingga peneliti datang langsung ke apotek tempat apoteker berpraktik. Kuesioner diadaptasi dari beberapa jurnal penelitian yang dilakukan oleh (Apriansyah et al., 2018), (Jabbar et al., 2017), (Lutfiyati et al., 2016), (Muharni et al., 2017) dan (Wahyuni et al., 2020) yang telah dimodifikasi oleh peneliti sesuai kebutuhan penelitian lalu kuesioner diberikan ke responden apoteker dalam apotek.

\section{Analisis Data}

Analisis data diawali dengan analisis instrumen. Analisis instrumen dilakukan dengan dua uji yaitu uji validitas dan uji reliabilitas. Pada uji validitas dilakukan untuk menilai keakuratan tiap item kuesioner dengan cara mengkorelasikan antara skor item dengan skor total dari semua item yang ada yang dibagikan kepada 30 responden. Selanjutnya dilakukan Uji Reliabilitas untuk mengetahui konsistensi alat ukur, apakah alat pengukur yang digunakan dapat diandalkan dan tetap konsisten jika pengukuran tersebut diulang. Pengujian tersebut dilakukan menggunakan bantuan sistem aplikasi IBM SPSS Statistics Version 26. Analisis Deskriptif 
dilakukan untuk menganalisis data dengan cara mendeskripsikan atau menggambarkan data yang telah terkumpul menjadi data tabel menggunakan Microsoft Excel 2007.

\section{Etika Penelitian}

Penelitian ini telah lolos uji etik dari Komite Etik Penelitian Fakultas Kedokteran Universitas Tadulako dengan nomor registrasi 2828/UN 28.1.30/KL/2021. Seluruh apoteker yang berpartisipasi dalam penelitian ini telah memberikan persetujuan dalam bentuk informed consent.

\section{HASIL}

\section{Uji Validitas dan Uji Reliabilitas}

Pada uji validitas, jumlah sampel (n) sebanyak 30 responden maka didapatkan nilai rtabel $=0,3610$. Setelah dilakukan pengujian didapatkan hasil pertanyaan yang valid sebanyak 24 pertanyaan dari 32 pertanyaan. Kuesioner dikatakan valid bila nilai rhitung $>$ rtabel. Pertanyaan yang telah valid selanjutnya akan dilakukan uji reliabilitas. Pada uji reliabilitas, Instrumen dapat dikatakan reliabel jika memenuhi kriteria bahwa Cronbach's Alpha > nilai batas. Hasilnya didapatkan nilai Cronbach's Alpha yaitu 0.934 dan nilai batas yaitu 0.60 . Hal ini menunjukkan bahwa untuk item pertanyaan yang telah valid sebanyak 24 item pada masingmasing variabel responden telah dapat menjawab secara konsisten atau reliabel.

\section{Gambaran Karakteristik Apoteker}

Data apoteker berupa identitas responden berdasarkan usia, jenis kelamin, lama pengalaman apotek, frekuensi kehadiran, lama tiap kali datang dan pekerjaan sampingan. Karakteristik apoteker dicantumkan pada tabel I.

Tabel 1 menunjukkan bahwa apoteker paling banyak berusia $\leq 30$ tahun yaitu 39 pasien (45.35\%). Jenis kelamin yang mendominasi yaitu jenis kelamin perempuan sebanyak 68 apoteker (79.07\%). Sebagian besar apoteker memiliki pengalaman kerja di apotek 1-5 tahun yaitu sebanyak 43 apoteker (50\%). Apoteker dengan frekuensi kehadiran tiap hari yaitu sebanyak 48 apoteker (55.81\%). Lama tiap kali datang apoteker paling banyak $>5$ jam/hari yaitu 39 apoteker (45.35\%) dan sebagian besar apoteker tidak memiliki pekerjaan sampingan sebanyak 51 apoteker $(59.30 \%)$. 
Tabel 1 Karakteristik Apoteker

\begin{tabular}{|c|c|c|}
\hline $\begin{array}{c}\text { Karakteristik } \\
\text { Apoteker }\end{array}$ & $\begin{array}{l}\text { Jumlah } \\
(\mathrm{n}=86)\end{array}$ & $\begin{array}{c}\text { Persentase } \\
(\%)\end{array}$ \\
\hline \multicolumn{3}{|l|}{ Usia } \\
\hline$\leq 30$ tahun & 39 & 45.35 \\
\hline $31-40$ tahun & 32 & 37.21 \\
\hline 41-50 tahun & 9 & 10.47 \\
\hline$>50$ tahun & 6 & 6.97 \\
\hline \multicolumn{3}{|l|}{ Jenis Kelamin } \\
\hline Perempuan & 68 & 79.07 \\
\hline Laki-laki & 18 & 20.93 \\
\hline \multicolumn{3}{|l|}{ Pengalaman di Apotek } \\
\hline$<1$ tahun & 7 & 8.14 \\
\hline $1-5$ tahun & 43 & 50 \\
\hline $6-10$ tahun & 17 & 19.77 \\
\hline$>10$ tahun & 19 & 22.09 \\
\hline \multicolumn{3}{|l|}{ Frekuensi Kehadiran } \\
\hline Sebulan Sekali & 9 & 10.47 \\
\hline Sebulan dua kali & 4 & 4.65 \\
\hline Seminggu 1-2 kali & 6 & 6.97 \\
\hline Seminggu 3-5 kali & 19 & 22.09 \\
\hline Tiap Hari & 48 & 55.81 \\
\hline \multicolumn{3}{|l|}{ Lama tiap kali datang } \\
\hline$<1$ jam/hari & 5 & 5.81 \\
\hline 1-3 jam/hari & 17 & 19.77 \\
\hline 3-5 jam/hari & 25 & 29.07 \\
\hline$>5$ jam/hari & 39 & 45.35 \\
\hline \multicolumn{3}{|l|}{ Pekerjaan Sampingan } \\
\hline Tidak Ada & 51 & 59.30 \\
\hline PNS Depkes & 17 & 19.77 \\
\hline PNS Non Depkes & 6 & 6.97 \\
\hline Wiraswasta & 12 & 13.95 \\
\hline
\end{tabular}

Keterangan. PNS Depkes : Pegawai Negeri Sipil Departemen Kesehatan

PNS Non Depkes : Pegawai Negeri Sipil Non Departemen Kesehatan

\section{Gambaran Karakteristik Apotek}

Data berupa identitas apotek berdasarkan lama berdiri, jam buka apotek, ada praktek dokter, jumlah TTK dan Status kepemilikan apotek. Jumlah apotek yang berpartisipasi sebanyak 86 apotek. Karakteristik apotek terdapat pada tabel 2. 
Tabel 2 Karakteristik Apotek

\begin{tabular}{ccc}
\hline $\begin{array}{c}\text { Karakteristik } \\
\text { Apotek }\end{array}$ & $\begin{array}{c}\text { Jumlah } \\
(\mathbf{n}=\mathbf{8 6})\end{array}$ & $\begin{array}{c}\text { Persentase } \\
(\%)\end{array}$ \\
\hline Lama Berdiri & & \\
3-5 tahun & 29 & 33.72 \\
$>5$ tahun & 57 & 66.28 \\
Jam buka apotek & & \\
$<=12$ jam & 10 & 11.63 \\
13-18 jam & 76 & 88.37 \\
Ada praktek dokter & & \\
Ya & 35 & 40.69 \\
Tidak & 51 & 59.30 \\
Jumlah TTK & & \\
1-2 orang & 68 & 79.07 \\
3-5 orang & 17 & 19.77 \\
6-10 orang & 1 & 1.16 \\
Status kepemilikan apotek & & \\
PSA & 58 & 32.56 \\
Milik sendiri & 28 &
\end{tabular}

Keterangan. TTK : Tenaga Teknis Kefarmasian

PSA : Pemilik Sarana Apotek

Tabel 2 menunjukkan bahwa lama berdirinya apotek paling banyak $>5$ tahun yaitu 57 apotek (66.28\%). Jam buka apotek yang mendominasi yaitu 13-18 jam sebanyak 76 apotek (88.37\%). Sebagian besar apotek tidak memiliki praktek dokter sebanyak 51 apotek (59.30\%). Apotek dengan jumlah tenaga teknis kefarmasian (TTK) paling banyak yaitu 1-2 orang sebanyak 68 apotek (79.07\%). Sebagian besar apotek status kepemilikannya oleh pemilik sarana apotek (PSA) sebanyak 58 apotek (67.44\%).

\section{Hasil Penelitian Mengenai Pelayanan Swamedikasi}

Kuesioner pelayanan swamedikasi oleh apoteker di kota palu terdiri atas 3 indikator yaitu penggalian informasi, pemilihan obat dan informasi obat. Penggalian informasi terdiri dari 10 pertanyaan, pemilihan obat terdiri dari 5 pertanyaan dan informasi obat terdiri dari 9 pertanyaan yang telah valid dan reliabel. 
Tabel 3 Hasil Penelitian Pelayanan Swamedikasi Oleh Apoteker di Kota Palu

\begin{tabular}{|c|c|c|c|}
\hline \multirow[b]{2}{*}{ No. } & \multirow[b]{2}{*}{ Variabel } & \multicolumn{2}{|c|}{ Kategori } \\
\hline & & Diterapkan & $\begin{array}{c}\text { Tidak } \\
\text { diterapkan }\end{array}$ \\
\hline \multicolumn{4}{|c|}{ Penggalian Informasi } \\
\hline 1. & Mendengarkan keluhan pasien & $95.35 \%$ & $4.65 \%$ \\
\hline 2. & Untuk siapa obat yang akan digunakan & $86.05 \%$ & $13.95 \%$ \\
\hline 3. & Gejala apa yang dirasakan oleh pasien & $97.67 \%$ & $2.33 \%$ \\
\hline 4. & Berapa lama gejala tersebut berlangsung & $90.70 \%$ & $9.30 \%$ \\
\hline 5. & Tindakan apa saja yang telah dilakukan & $74.42 \%$ & $25.58 \%$ \\
\hline 6. & Obat apa yang telah digunakan oleh pasien & $91.86 \%$ & $8.14 \%$ \\
\hline 7. & Riwayat penyakit dari pasien & $84.88 \%$ & $15.12 \%$ \\
\hline 8. & Adanya alergi obat pada pasien & $86.05 \%$ & $13.95 \%$ \\
\hline 9. & Pasien sedang hamil atau menyusui & $79.07 \%$ & $20.93 \%$ \\
\hline 10. & Hal lain selain pertanyaan yang sebelumnya & $50 \%$ & $50 \%$ \\
\hline & Rata-rata & $83.61 \%$ & $16.39 \%$ \\
\hline \multicolumn{4}{|c|}{ Pemilihan Obat } \\
\hline 11. & Obat sesuai dengan keluhan pasien & $100 \%$ & 0 \\
\hline 12. & $\begin{array}{l}\text { Obat dengan golongan obat bebas dan } \\
\text { bebas terbatas }\end{array}$ & $96.51 \%$ & $3.48 \%$ \\
\hline 13. & $\begin{array}{l}\text { Obat dalam jumlah yang tepat kepada } \\
\text { pasien }\end{array}$ & $100 \%$ & 0 \\
\hline 14. & $\begin{array}{l}\text { Memastikan keamanan produk obat sebelum } \\
\text { diberikan kepada pasien }\end{array}$ & $100 \%$ & 0 \\
\hline 15. & Indikasi resmi dari produk obat & $80.23 \%$ & $19.76 \%$ \\
\hline & Rata-rata & $95.35 \%$ & $4.65 \%$ \\
\hline \multicolumn{4}{|c|}{ Informasi Obat } \\
\hline 16. & Informasi khasiat obat & $97.67 \%$ & $2.32 \%$ \\
\hline 17. & Cara pemakaian obat kepada pasien & $100 \%$ & 0 \\
\hline 18. & Waktu pemakaian obat kepada pasien & $100 \%$ & 0 \\
\hline 19. & Lama penggunaan obat kepada pasien & $88.37 \%$ & $11.62 \%$ \\
\hline 20. & Efek samping obat kepada pasien & $81.39 \%$ & $18.60 \%$ \\
\hline 21. & Kontra indikasi obat kepada pasien & $87.21 \%$ & $12.79 \%$ \\
\hline 22. & $\begin{array}{l}\text { Hal yang harus diperhatikan sewaktu minum } \\
\text { obat kepada pasien }\end{array}$ & $93.02 \%$ & $6.97 \%$ \\
\hline 23. & Cara penyimpanan obat kepada pasien & $87.20 \%$ & $12.79 \%$ \\
\hline \multirow[t]{2}{*}{24.} & $\begin{array}{l}\text { Apa yang harus dilakukan ketika lupa } \\
\text { meminum obat }\end{array}$ & $72.09 \%$ & $27.90 \%$ \\
\hline & Rata-rata & $89.66 \%$ & $10.34 \%$ \\
\hline
\end{tabular}

\section{PEMBAHASAN}

Apoteker dianggap sebagai ahli dalam mengembangkan dan menyiapkan obat. Pada saat yang bersamaan, apoteker juga diharapkan dapat memberikan konsultasi kepada pasien dan memantau setiap masalah yang mungkin terjadi selama penggunaan obat, yang disebut dengan masalah terkait obat. Sebagai bagian dari pelayanan obat saat ini, apoteker juga diharapkan dapat membantu dalam memberikan resep pengobatan obat yang terbaik bahkan rencana pengobatan yang terbaik. Dalam definisi ini aspek kepedulian terhadap pemberian obat sangat ditekankan. Banyak apoteker telah menerima pengobatan, tetapi yang lain masih belum tahu bagaimana membentuknya di lingkungan praktik mereka (Dahri, 2019). 
Jika dilihat dari persentase rata-rata didapatkan pelayanan penggalian informasi masuk kedalam kategori baik yaitu dengan persentase $83,60 \%$. Menurut Yusuf (2016), pelayanan dikategorikan cukup apabila persentase berada pada rentang $65 \%-83 \%$. Tujuan penggalian informasi adalah untuk menilai pasien yang meliputi keamanan, akurasi dan kewajaran tindakan pasien. Hal tersebut perlu dilakukan apoteker untuk menentukan pemilihan obat yang tepat terhadap pasien. Pada item nomor 1 sampai 6 merupakan informasi yang paling sering digali oleh apoteker dikarenakan pada pelayanan penggalian informasi, metode yang dilakukan apoteker yaitu metode WWHAM (What, What Symptoms, How Long, Action dan Medicine) yang berisi 5 pertanyaan penuntun sistematis untuk menggali informasi dari pasien yang meminta obat tanpa resep (Muharni et al., 2017). Sebaliknya pada item nomor 7 sampai 9 merupakan pertanyaan lain untuk menunjang lengkapnya informasi antara lain riwayat penyakit pasien, alergi obat, pasien hamil atau menyusui dan lain-lain.

Apoteker yang bekerja di apotek dapat membantu pasien dengan pelayanan swamedikasi yaitu memberikan pelayanan pemilihan obat yang tepat kepada pasien. Berdasarkan hasil dari penelitian ini didapatkan, persentase pelayanan pemilihan obat yaitu 95,35\% dan masuk dalam kategori sangat baik. Menurut Yusuf (2016), pelayanan dikategorikan sangat baik apabila persentase berada pada rentang $84 \%-100 \%$. Apoteker dapat memilih obat bebas, bebas terbatas, dan obat wajib apotek (OWA) untuk penyakit ringan antara lain nyeri, diare, demam, batuk dan gejala lain yang dapat diobati tanpa resep dokter. Apoteker juga dapat menekankan pada pasien bahwa meskipun obat ini tersedia tanpa resep dokter, obat ini tetap dapat menimbulkan efek yang tidak diinginkan jika dikonsumsi dengan tidak tepat (Wahyuni et al., 2020). Pada item nomor 11, 13 dan 14 paling banyak dilakukan dalam pemilihan obat karena harus disesuaikan dengan kebutuhan pasien, obat yang diberikan juga harus dalam jumlah yang tepat agar tidak menimbulkan efek samping jika penggunaannya terlalu banyak atau sedikit serta obat yang diberikan harus dalam kondisi layak konsumsi bukan obat yang sudah kadaluwarsa atau rusak. Sebaliknya pada item nomor 15 tidak terlalu diperlukan karena umumnya obat telah diproduksi sesuai indikasi tertentu.

Apoteker bertanggung jawab terhadap pasien dalam memberikan informasi obat. Selain berorientasi terhadap pasien sebagai bentuk pelayanan kefarmasian (Pharmaceutical care) hal ini juga dapat dimanfaatkan sebagai alat promosi untuk apotek. Jika dilihat dari rata-rata persentase didapatkan bahwa pelayanan informasi obat masuk dalam kategori sangat baik yaitu 89,66\%. Menurut Yusuf (2016), pelayanan dikategorikan baik apabila persentase berada pada rentang $84 \%-100 \%$. Tujuan pemberian informasi yaitu untuk mendorong penggunaan obat yang tepat dan logis, memantau pemakaian obat dan mengurangi risiko kesalahan pengobatan serta bagian dari edukasi agar pasien memperhatikan kesehatannya secara serius dan bijak memahami obat yang akan diminum dan cara 
penggunaannya yang benar. Pada item nomor 16 sampai 20 dan 23 paling banyak dilakukan dalam pemberian informasi obat karena informasi yang seharusnya didapatkan pasien antara lain khasiat obat, cara pemakaian obat, lama penggunaan obat, cara penyimpanan obat, efek samping obat, waktu pemakaian obat yang seharusnya diberikan oleh apotek dan merupakan hak pasien jadi tidak hanya cara dan aturan pakai obat. Informasi yang lengkap dan jelas akan mengurangi risiko terjadinya medication error (Winanto, 2013). Sedangkan pada item nomor 21, 22 dan 24 jarang dilakukan karena pengobatan dalam swamedikasi selalu memberikan terapi dengan obatobatan yang minim kontra indikasi dan tidak menimbulkan efek yang berbahaya.

Pada penelitian ini apoteker dalam apotek di kota palu sudah melaksanakan pelayanan swamedikasi dengan baik sesuai dengan variabel dan masuk dalam kategori sangat baik. Akan tetapi dengan melihat kehadiran apoteker hanya $55.81 \%$ perlu adanya analisis lebih lanjut sebenarnya yang memberikan pelayanan swamedikasi ini apoteker atau tenaga teknis kefarmasian (TTK).

\section{SIMPULAN}

Apoteker dalam melaksanakan swamedikasi, menerapkan penggalian informasi sebanyak $83,60 \%$, menerapkan pemilihan obat sebanyak $95,35 \%$ dan menerapkan pemberian informasi obat sebanyak 89,66\%. Apoteker dalam apotek sudah melaksanakan pelayanan swamedikasi dengan baik sesuai variabel dan masuk dalam kategori sangat baik. Limitasi penelitian ini yaitu tidak melakukan analisis terhadap variabel monitoring efek samping obat (MESO) dan Pemantauan terapi obat (PTO).

\section{REFERENSI}

Apriansyah, A., Saibi, Y., Karyadi, 2018, Clinical Pharmacy Service At Community Pharmacy In South Tangerang Regency, Journal of Pharmacopolium, 1(2):81-87. https://doi.org/http://dx.doi.org/10.36465/jop.v1i2.329

Candradewi, S. F., Kristina, S. A., 2017, Gambaran Pelaksanaan Swamedikasi Dan Pendapat Konsumen Apotek Mengenai Konseling Obat Tanpa Resep di Wilayah Bantul. Pharmaciana. https://doi.org/10.12928/pharmaciana.v7i1.5193

Dahri, K., 2019, The Pharmacist Guide to Implementing Pharmaceutical Care, The Canadian Journal of Hospital Pharmacy, 72(2). https://doi.org/10.4212/cjhp.v72i2.2889

Jabbar, A., Nurjannah, N., Ifayah, M., 2017, Studi Pelakasanaan Pelayanan Swamedikasi Beberapa Apotek Kota Kendari. Warta Farmasi, 6(1):28-36. https://doi.org/10.46356/wfarmasi.v6i1.69

Lubis, F. R. W., 2014, Evaluasi Tingkat Kesalahan Pengobatan Sendiri (Swamedikasi) di Kalangan Mahasiswa Universitas Sumatra Utara. Universitas Sumatra Utara.

Lutfiyati, H., Yuliastuti, F., Dianita, P. S., 2016, Pelaksanaan Konseling Oleh Apoteker di Apotek Kecamatan Temanggung, Jurnal Farmasi Sains dan Praktis, 2(1): 24-28. https://doi.org/10.31603/pharmacy.v2i1.184

Muharni, S., Aryani, F., Agustini, T. T., Fitriani, D., 2017, Sikap Tenaga Kefarmasian Dalam Penggalian Informasi Pada Swamedikasi Nyeri Gigi di Apotek-Apotek Kota Pekanbaru Provinsi Riau. Jurnal Penelitian Farmasi Indonesia, 5(2):67-73.

Osemene, K. P., Lamikanra, A., 2012, A Study of The Prevalence of Self-Medication Practice Among University Students In Southwestern Nigeria. Tropical Journal of Pharmaceutical Research, 11(4):683-689. https://doi.org/10.4314/tjpr.v11i4.21 
Rees, J. A., 2013, Pharmaceutical Practice. In Journal of Chemical Information and Modeling, 53(9)

Wahyuni, K. I., Permatasari, N. E., Fickri, D. Z., Amarullah, A., 2020, Evaluasi Pelayanan Swamedikasi Di Apotek Wilayah Sidoarjo, Jurnal Pharmascience, 7(1), 25-35 https://doi.org/10.20527/jps.v7i1.8083.

Widyaningsih, D. W., 2018, Pendalaman Materi Farmasi: Pelayanan Swamedikasi, 1-23.

Winanto, A., 2013, Persepsi Konsumen Terhadap Pelayanan Apotek Di Kota Ranai Kecamatan Bunguran Timur Kabupaten Natuna, 1-8, Universitas Tanjungpura.

Yusuf, M., 2016, Metode Penelitian: Kuantitatif, Kualitatif dan Penelitian Gabungan. Kencana.

Zeenot, S., 2013, Pengelolaan dan Penggunaan Obat Wajib Apotek. D-Medika.

\section{UCAPAN TERIMA KASIH}

Terima kasih kami ucapkan kepada apoteker di Kota Palu yang telah bersedia sebagai responden dalam penelitian ini serta pihak lainnya yang membantu jalannya penelitian ini

\section{KONTRIBUSI PENULIS}

DS berkontribusi dalam pengumpulan data, analisis statistik dan semua penulis berkontribusi pada interpretasi data dan menyetujui versi akhir naskah.

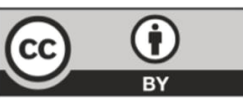

Akses Terbuka Artikel ini dilisensikan di bawah Creative Commons Lisensi Internasional Attribution 4.0, yang memungkinkan penggunaan, berbagi, adaptasi, distribusi, dan reproduksi dalam media atau format apa pun, selama Anda memberikan kredit yang sesuai kepada penulis asli dan sumbernya, memberikan tautan ke lisensi Creative Commons, dan Menerangkan jika perubahan telah dilakukan. Gambar atau materi pihak ketiga lainnya dalam artikel ini termasuk dalam lisensi Creative Commons artikel, kecuali dinyatakan sebaliknya dalam batas kredit untuk materi tersebut. Jika materi tidak termasuk dalam lisensi Creative Commons artikel dan penggunaan yang Anda maksudkan tidak diizinkan oleh peraturan perundang-undangan atau melebihi penggunaan yang diizinkan, Anda harus mendapatkan izin langsung dari pemegang hak cipta. Untuk melihat salinan lisensi ini, kunjungi https://creativecommons.org/licenses/by/4.0/deed.id.

(C) The Author(s) 2021 